\title{
SYNTHESIS OF AU (III) POLYACRYLATES AND STUDY OF THEIR TUMORICIDAL ACTIVITY
}

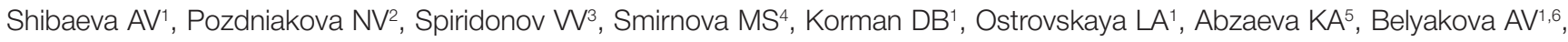
Biryukova YuK ${ }^{1,6}$, Zylkova MV ${ }^{1}$, Ivanov KP7 , Shevelev $A B^{4} \square$, Kuzmin VA

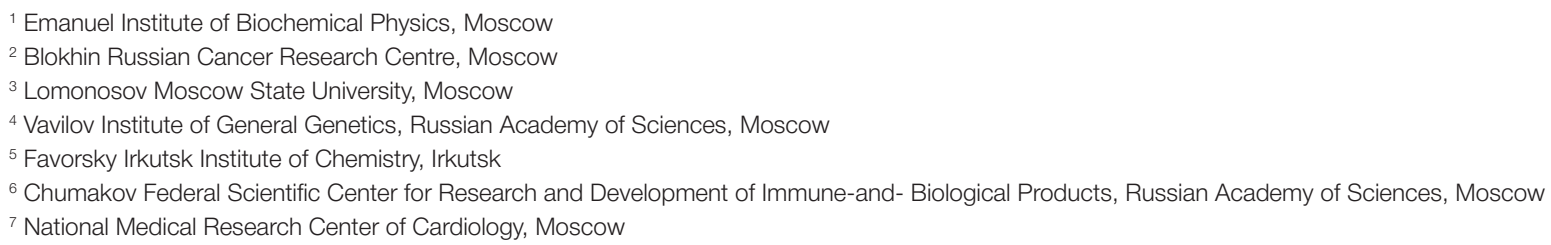

Aurumacryl is an incomplete metal salt of poly(acrylic acid) that exhibits hemostatic activity and inhibits the growth of transplantable carcinomas in vivo. The samples of aurumacryl synthesized following the original technique are insufficiently soluble, which complicates the study of the mechanisms involved in their synthesis and underlying their cytotoxic effect. The aim of this work was to study the impact of the following factors on aurumacryl properties: the molecular weight of the polyacrylate polymer in a range between 2 and $1,000 \mathrm{kDa}$, the presence of a counterion $\mathrm{H}^{+}$or $\mathrm{Na}^{+}$, the molar ratio of $\mathrm{AuCl}^{-}$ to the polyacrylate polymer $(1: 5$ and $1: 10)$, the total concentration of the polyacrylate polymer during synthesis $(0.1$ and $3 \%$ ), and the type of drying (lyophilization). By comparing the cytotoxicity of aurumacryl samples with significantly different molar ratio of gold ions to the polyacrylate polymer against human breast carcinoma cells (MCF-7), we established that the proportion of the polymer and its molecular weight in the sample do not affect the biological properties of the synthesized substance. Using UV spectroscopy, we revealed that the concentration of Au (III) ions in aurumacryl determines its cytotoxicity.

Keywords: aurumacryl, polyacrylate, chloroauric acid tetrahydrate, antitumor therapy, cytotoxicity, MCF-7

Funding: the study was supported by the Ministry of Science and Higher Education of the Russian Federation (Subsidy Contract 14.607.21.0199 dated 26.09.2017, Project ID RFMEFI60717X0199). Spectroscopy was performed at the Shared Research Facility of Favorsky Irkutsk Institute of Chemistry, RAS.

Correspondence should be addressed: Alexei B. Shevelev

Gubkina 3, Moscow, 119991; shevel_a@hotmail.com

Received: 28.09.2018 Accepted: 26.10.2018

DOI: $10.24075 /$ brsmu.2018.071

\section{СИНТЕЗ И ИССЛЕДОВАНИЕ ПРОТИВООПУХОЛЕВОЙ АКТИВНОСТИ ПОЛИАКРИЛАТОВ ЗОЛОТА (III)}

А. В. Шибаева ${ }^{1}$, Н. В. Позднякова², В. В. Спиридонов ${ }^{3}$, М. С. Смирнова ${ }^{4}$, Д. Б. Корман ${ }^{1}$, Л. А. Островская ${ }^{1}$, К. А. Абзаева А. В. Белякова ${ }^{1,6}$, Ю. К. Бирюкова ${ }^{1,6}$, М. В. Зылькова ${ }^{1}$, К. П. Иванов , А. Б. Шевелев ${ }^{4}$, В. А. Кузьмин

${ }^{1}$ Институт биохимической физики имени Н. М. Эмануэля РАН, Москва

${ }^{2}$ Национальный медицинский исследовательский центр онкологии имени Н. Н. Блохина, Москва

${ }^{3}$ Московский государственный университет имени М. В. Ломоносова, Москва

${ }^{4}$ Институт общей генетики имени Н. И. Вавилова, Москва

${ }^{5}$ Иркутский институт химии имени А. Е. Фаворского, Иркутск

${ }^{6}$ Федеральный научный центр исследований и разработки иммунологических препаратов имени М. П. Чумакова РАН, Москва

${ }^{7}$ Национальный медицинский исследовательский центр кардиологии, Москва

Аурумакрил проявляет гемостатическую активность и обладает онколитическим и онкостатическим действием в отношении перевиваемых карцином in vivo. Образцы аурумакрила, полученные по известной методике, недостаточно стандартизированы по растворимости, что не позволяет изучить механизмы реакции и цитостатического действия. Целью работы было исследовать влияние на свойства аурумакрила следующих параметров проведения реакции его синтеза: молекулярная масса полиакрилатного полимера (в диапазоне 2-1000 кДа), наличие в качестве противоиона $\mathrm{H}^{+}$ или $\mathrm{Na}^{+}$, соотношение иона тетрахлораурата и звена полиакрилатного полимера (1: 5 или $\left.1: 10\right)$, общая концентрация полиакрилатного полимера в момент синтеза (0,1 или 3\%), а также влияние лиофильного высушивания аурумакрила. Сопоставление цитотоксической активности полученных образцов аурумакрила со значительно различающимся соотношением ионов золота и полиакрилатного полимера в отношении клеток карциномы молочной железы человека MCF-7 позволило установить, что удельное содержание в препарате полиакрилатного полимера и его молекулярная масса практически не сказываются на биологических свойствах конечного продукта. Методом УФ-спектроскопии показано влияние концентрации ионов Au (III) в аурумакриле на их цитотоксическую активность.

Ключевые слова: аурумакрил, полиакрилат, золотохлористоводородная кислота, тетрахлораурат, протовоопухолевое средство, цитотоксическая активность, MCF-7

Финансирование: исследование поддержано Министерством образования и науки Российской Федерации (Соглашения о представлении субсидии № 14.607.21.0199 от 26.09.2017, уникальный идентификатор RFMEFI60717Х0199). Спектроскопические измерения проведены на базе ЦКП «Новые материалы и технологии» ИБХФ РАН.

$\triangle$ Для корреспонденции: Алексей Борисович Шевелев ул. Губкина, д. 3, г. Москва, 119991; shevel_a@hotmail.com

Статья получена: 28.09.2018 Статья принята к печати: 26.10.2018

DOI: 10.24075/vrgmu.2018.071 
Aurumacryl first described in [1] is an incomplete metal salt of poly(acrylic acid) (PAA) containing gold (III) ions. Based on the amount of the initial reactants consumed during aurumacryl synthesis, it was concluded that the final metal wt\% in the substance would be $8.03 \%$ whereas the molecular weight of the polymer would fall within the range between 100 and 300 kDA. The chemical formula of aurumacryl is

$$
\left(-\mathrm{CH}_{2}-\mathrm{CHCOOH}-\right)_{n}\left(-\mathrm{CH}_{2} \mathrm{CHCOOAuCl}{ }_{3} \mathrm{H}-\right)_{m} \text {, }
$$

where $n=1,263$ and $m=124$.

In the original study, aurumacryl was synthesized by combining aqueous PAA solutions and chloroauric acid tetrahydrate $\left(\mathrm{HAuCl}_{4}\right)$ at room temperature [1]. Briefly, $\mathrm{HAuCl}_{4}$ was taken in the amount sufficient to produce $8.3 \%$ wt of gold in the resulting gold polyacrylate and added to a 5.7\% PAA solution (the molar mass of the solute $M_{r}$ was 100,000 ). The reaction mixture was stirred, and the solution was then left in a vacuum desiccator. The resulting substance was a dense yellow film. Its physical and chemical properties can be inferred from the absorption bands of its IR spectra characteristic of carboxyl and carboxylate groups at 1,720 and $1,570 \mathrm{~cm}^{-1}$ wavelengths, respectively. However, the actual content of aurumacryl components in the resulting compound, including polyacrylic acid, gold ions (III), gold ions (I), elemental gold, and other anions and cations, cannot be deduced from the presented data.

The aim of this work was to improve the technique for aurumacryl synthesis in order to obtain a chemically stable standard preparation sufficiently soluble in water and to elaborate a method for testing aurumacryl quality thereby predicting its biological activity. The substance was synthesized using commercially available PAA and sodium polyacrylate (PANa) with known molecular weights. The molar ratio between $\mathrm{AuCl}_{4}^{-}$anions and PAA in the reaction mixture was $1: 5$ and $1: 10$.

Unlike our colleagues, we thoroughly desalted the PAA polymer by continuous-flow dialysis, which took a few days, and dried the solutions of the obtained polymer-gold complexes in a freeze dryer instead of leaving them to air-dry. The lyophilized aurumacryl samples were cryopreserved in liquid nitrogen and vacuumized.

To evaluate our improved method of synthesis, we tested aurumacryl for solubility and cytotoxicity against MCF7 cells, measured the amount of gold salts in the produced samples by UV-spectroscopy, and estimated the content of gold nanoparticles in aurumacryl using transmission electron microscopy.

\section{METHODS}

\section{Reagents}

Commercially available PAA and PANa (Sigma Aldrich; USA) with different polymerization degrees (i.e., the average number of monomers per molecule) of 23; 80; 160; 1,389; 1,944; 3,472 ; and 13,889 were used as starting materials. The average degree of polymerization and polymer dispersion properties were specified by the manufacturer. Another component used for aurumacryl synthesis was dry chloroauric acid (Aurat; Moscow) with $48 \%$ gold content.

\section{Preparing polyacrylic polymers for synthesis}

For synthesis we chose PAA with an average molecular weight of 1,633 Da, 11,360 Da, 100,000 Da, 140,000 Da, 250,000
$\mathrm{Da}$, and 1,000,000 Da (the molecular weight was specified by the manufacturer) and sodium polyacrylate (SigmaAldrich; USA) with an average molecular weight of 2,100 Da, 15,000 Da, 132,350 Da, 185,370 Da, 330,980 Da, and 1,324,000 Da.

Prior to synthesis, all PAA samples were additionally purified by flow dialysis continued for several days and thoroughly dried by freezing.

Then, weighted amounts of the polymers $(50 \mathrm{mg})$ were dissolved at room temperature in 50 and $1.67 \mathrm{ml}$ of water to obtain $0.1 \%$ and $3 \%$ wt polymer solutions, respectively. During the 12-h process the polymers were continuously stirred on the magnetic stirrer.

\section{Aurumacryl synthesis}

Chloroauric acid was added to the solutions of pre-deionized polymers as described below:

- $50 \mu \mathrm{L}$ of the aqueous solutions containing 23.8 and $47.6 \mathrm{mg}$ of chloroauric acid were added dropwise to $0.1 \% \mathrm{wt}$ PAA solutions;

- $30 \mu \mathrm{L}$ of the aqueous solutions containing 23.8 and $47.6 \mathrm{mg}$ of chloroauric acid were added dropwise to $0.3 \% \mathrm{wt}$ PAA solutions;

- $50 \mu \mathrm{L}$ of the aqueous solution containing 18.4 and $36.7 \mathrm{mg}$ of chloroauric acid were added dropwise to $0.1 \% \mathrm{wt}$ PANa solutions;

- $30 \mu \mathrm{L}$ of the aqueous solution containing 23.8 and $47.6 \mathrm{mg}$ of chloroauric acid were added dropwise to $0.3 \% \mathrm{wt}$ PAA solutions.

Synthesis was carried out at room temperature and took $24 \mathrm{~h}$. The reaction mixture was continuously stirred on the magnetic stirrer at $60 \mathrm{rpm}$.

Low molecular weight components were separated from the obtained solutions by continuous-flow dialysis using MWCO 15,000 dialysis tubing. The solutions of gold-polymer complexes (1.7-20 ml) were poured into the tubing and dialyzed against water for $3 \mathrm{~h}$ at room temperature.

After that, the solutions were frozen at $-70{ }^{\circ} \mathrm{C}$ and lyophilized, except for a few samples that were not freeze-dried but stored at $+4{ }^{\circ} \mathrm{C}$ under aseptic conditions instead.

\section{Determining solubility of aurumacryl samples}

Solubility was determined for each of the obtained dry aurumacryl samples. Briefly, $100 \mu \mathrm{L}$ water aliquots were added one by one to $1 \mathrm{mg}$ of the sample at room temperature and its behavior was monitored for $30 \mathrm{~min}$. If the sample did not dissolve, another water aliquot was added to it. The procedure was repeated until complete dissolution was achieved.

\section{Measuring the conversion of gold ions in concentrated aurumacryl solutions}

The conversion of gold ions was measured in $100 \mathrm{mM} \mathrm{HCl}$ at $\lambda=226.5 \mathrm{~nm}$. For the measurements, we took a $10 \mu \mathrm{L}$ aliquot of a concentrated solution obtained in the previous solubility assessment step and $10 \mu \mathrm{L}$ of a solution that was not dried immediately after the synthesis. The aliquot was introduced into $3 \mathrm{ml}$ of a $100 \mathrm{mM} \mathrm{HCl}$ solution and then its absorbance $A_{226.5}$ at $226.5 \mathrm{~nm}$ was measured. The conversion of gold salts was determined for each sample based on the calculated $A_{226.5}$ $(\approx[\mathrm{HAuCl}], \mu \mathrm{M})$ relative to the total solids concentration (the residual moisture in the dry sample was ignored). For further toxicity experiments in MCF-7 cells, concentrations of all samples were normalized based on absorbance at $\lambda=226.5$. 


\section{Studying the cytotoxic activity of aurumacryl samples in the MCF-7 cell line with an MTT assay}

Five thousand cells were seeded onto the Costar 96-well plate containing $180 \mu \mathrm{L}$ of the DMEM medium (Paneco; Russia) per well supplemented with $10 \%$ fetal bovine serum. The cells were cultured at $37{ }^{\circ} \mathrm{C}$ and $5 \% \mathrm{CO}_{2}$ for $24 \mathrm{~h}$. Then $20 \mu \mathrm{L}$ of the aqueous aurumacryl solution with the normalized concentration (absorbance at $226.5 \mathrm{~nm}$ ) were added into each well and continued incubation at $37^{\circ} \mathrm{C}$ and $5 \% \mathrm{CO}_{2}$ for $24 \mathrm{~h}$. After that, $10 \mu \mathrm{L}$ of the MTT reagent 3-(4,5-dimethylthiazol-2yl)-2,5-diphenyltetrazolium bromide (item 57360-69-7; Sigma Aldrich; USA) were added at a final concentration of $0.5 \mathrm{mg} / \mathrm{ml}$ to the culture, and the cells were incubated for $3 \mathrm{~h}$. Absorbance from the wells $A_{570}$ at $570 \mathrm{~nm}$ was measured by the Multiskan Go spectrophotometer (Thermo Fisher Scientific; USA).

\section{Measuring the proportion of gold nanoparticles in aurumacryl samples by transmission electron microscopy}

A $3 \mu \mathrm{L}$ aliquot of the aqueous aurumacryl solution containing $1-5 \mu \mathrm{g}$ of the gold-polymer complex was applied onto the Fine 200 Copper Grid Mesh (SPI Supplies; USA) with a diameter of $3.5 \mathrm{~mm}$, air-dried for $5 \mathrm{~min}$ and vacuumized. The analysis was carried out using the JEM-100B microscope (JEOL; Japan) at the accelerating voltage of $120 \mathrm{kV}$. The microscope was equipped with an accessory for $\mathrm{X}$-ray phase-contrast imaging.

The images of the particles detected within the field of view were analyzed in ImageJ (a free software by the National Institutes of Health; USA): the square area of each dark spot was calculated allowing for the zoom factor. At least 10 randomly chosen fields of view were analyzed for each sample. Once the linear sizes of the particles and their number was identified, we calculated the proportion of the particles falling within each of 5 diameter ranges of 1-10, 11-20, 20-50, 50-100, and >100 $\mathrm{nm}$ in Windows Excel.

\section{RESULTS}

We synthesized 23 aurumacryl samples from PAA and sodium polyacrylate with various molecular weights at 2 different molar ratios between $\mathrm{AuCl}_{4}$ and PAA of 1:5 and 1:10; the initial polymer concentration in the reaction mixture was $3 \%$ or $0.1 \%$.

A total of 10 freeze-dried samples were re-dissolved in water showing good solubility.

Chloroauric acid is known to undergo gradual hydrolysis in aqueous solutions with neutral and alkaline $\mathrm{pH}$; the reaction produces hydrochloric acid, which increases the acidity of the medium [2]. At $\mathrm{pH}<1$ this reaction is impossible. In our experiment, the aqueous solution of chloroauric acid in $100 \mathrm{mM}$ $\mathrm{HCl}$ had an absorbance peak at $\lambda=226.5 \mathrm{~nm}$, the extinction coefficient $\varepsilon$ being $3.5 \times 10^{4} \mathrm{l} \cdot \mathrm{mol}^{-1} \cdot \mathrm{cm}^{-1}$. These values are consistent with the published literature [2]. For the polyacrylates synthesized in the course of our experiment the extinction coefficient was below $10^{6} \mid \cdot \mathrm{mol}^{-1} \cdot \mathrm{cm}^{-1}$. Gold nanoparticles had zero absorbance at $\lambda=226.5 \mathrm{~nm}$, except for the light scatter effects. Therefore, we measured the proportion of gold ions in the synthesized substance at $\lambda=226.5 \mathrm{~nm}$ in $100 \mathrm{mM} \mathrm{HCl}$ (see Methods).

To test a hypothesis that the cytotoxic activity of aurumacryl is determined by the proportion of Au (III) in the substance, the solutions of the synthesized aurumacryl samples and the control sample prepared following the original technique (sample 1) were normalized to the Au (III) concentration calculated from absorbance at $\lambda=226.5 \mathrm{~nm}$. The solutions were tested for cytotoxicity at concentrations of $9.1 \mathrm{mU} / \mathrm{ml}$ (the $\mathrm{IC}_{50}$ of the control sample) and $91.0 \mathrm{mU} / \mathrm{ml}$, which is 10 times higher than the $\mathrm{IC}_{50}$ of the control sample. The results were averaged based on 3 independent measurements and are presented in Table 1.

Although concentrations of Au ions expressed as $\mu \mathrm{mol} / \mathrm{mg}$ differed between the solutions, all normalized aurumacryl samples exhibited the same cytotoxic potency as the control aurumacryl sample prepared following the original technique. The biological activity of the normalized aurumacryl samples was identical both at concentrations equaling $\mathrm{IC}_{50}$ of the control sample and at those 10 times higher than $\mathrm{IC}_{50}$. This proves that in vitro cytotoxicity of aurumacryl is determined by $\mathrm{Au}$ ions. The polymer component of the compound seems to work as a shield protecting Au ions from the interaction with other organic molecules that can reduce them to inactive gold nanoparticles.

We hypothesized that lower conversion of gold ions in the process of aurumacryl synthesis is due to their spontaneous reduction to elemental gold that aggregates into nanoparticles. To test this hypothesis, we studied a few synthesized aurumacryl samples by transmission electron microscopy (TEM) (Table 2).

The bigger was the molecular weight of the polymer used for aurumacryl synthesis, the higher was the proportion of gold nanoparticles sized $>10 \mathrm{~nm}$, which in essence are aggregates of smaller particles under $10 \mathrm{~nm}$ in size. Regardless of PAA molecular weight, the proportion of aggregated nanoparticles, as compared to the proportion of unaggregated, increased dramatically when the molar ratio of Au (III) to PAA was reduced from $1: 5$ to $1: 10$. When PANa was used instead of PAA as the starting component for aurumacryl synthesis, the average size of gold nanoparticles increased and more pronounced aggregation of gold nanoparticles was observed. For example, in the samples synthesized from PANa with polymerization degrees of 3,472 and 13,889 at the 1: 10 molar ratio between gold ions and PANa, the proportion of gold nanoparticles sized $\sim 100 \mathrm{~nm}$ was $75 \%$. In other samples synthesized from PANa, such nanoparticles were not detected. The control aurumacryl sample synthesized following the original technique contained a remarkably high proportion of gold nanoparticles with an average diameter of $20-50 \mathrm{~nm}$, which exceeded the proportion of such nanoparticles in other tested samples several-fold.

To validate our hypothesis about the cytotoxicity of aurumacryl samples being dependent on the proportion of $\mathrm{Au}$ ions and independent of the proportion of polyacrylate, elemental gold and other components, the most active samples 3, 10 and 17 (Table 1) were scrutinized for their cytotoxic activity against MCF-7 cells. The aurumacryl solutions were normalized to ion gold concentrations based on absorbance at $\lambda=226.5$ $\mathrm{nm}$ in $100 \mathrm{mM} \mathrm{HCl}$. Aurumacryl synthesized following the original technique was used as a control sample. The results of the test are shown in Fig. 1.

The correlation between the cytotoxic activity of the sample and the Au (III) concentration was the same for samples 3 and 10 , as well as for the control sample, although the samples were different in their composition and the applied method of synthesis. Sample 3 was synthesized from PAA with an average molecular weight of $1.6 \mathrm{kDa}$ (low polymerization degree) and was freeze-dried immediately after synthesis. Sample 10 was synthesized from PAA with a molecular weight of $250 \mathrm{kDa}$ and was stored as a solution. The molar ratio of gold ions to PAA in the reaction was 1: 32 for the control sample and 1: 10 for samples 3 and 10. Thus, the tested samples had different solubility and a different molar ratio of Au (III) to PAA. Table 2 suggests that the samples may have contained 
different proportions of gold nanoparticles. However, after the concentrations of the tested samples were normalized to $\mathrm{Au}$ (III), they exhibited identical cytotoxicity against the MCF-7 cells.

The correlation between the cytotoxic activity of sample 17 synthesized from PANa with an average molecular weight of $5.75 \mathrm{kDa}$ and spared from freeze-drying and the concentration of gold ions in it implies that sample 17 has some properties missing by other samples. At low concentrations in the solution $(0-10 \mathrm{mU} / \mathrm{ml})$ its cytotoxicity is higher than that of the samples synthesized from PAA whereas at higher concentrations of 25 and $90 \mathrm{mU} / \mathrm{ml}$ its cytotoxic potency is worse. It means that the interactions between chloroauric acid and PAA and between chloroauric acid and PANa produce substances in which the biological activity of Au ions is slightly different.

Aurumacryl synthesized from PANa (as opposed to PAA) can hardly be used in clinical practice because of its insufficient chemical stability during storage. Regardless of the molecular weight of the polymer, both solutions and lyophilisates have a tendency to the spontaneous reduction of $\mathrm{Au}$ ions that subsequently form gold nanoparticles, which causes a dramatic decline in their cytotoxicity.

Table 1. Synthesis conditions, physical, chemical and biological properties of aurumacryl samples

\begin{tabular}{|c|c|c|c|c|c|c|c|c|c|}
\hline \multirow{2}{*}{$\begin{array}{c}\text { Sample } \\
\text { ID }\end{array}$} & \multirow{2}{*}{$\begin{array}{c}\text { Concentration } \\
\text { of the initial } \\
\text { polymer } \\
\text { during } \\
\text { synthesis, } \\
\% w t\end{array}$} & \multirow{2}{*}{$\begin{array}{l}\text { Mr of } \\
\text { the initial } \\
\text { polymer, } \\
\text { kDa }\end{array}$} & \multirow[t]{2}{*}{ Counterion } & \multirow{2}{*}{$\begin{array}{c}\text { Molar ratio } \\
\text { between Au } \\
\text { (III) anions and } \\
\text { PAA or PANa } \\
\text { in the reaction } \\
\text { mixture, } \\
\text { mol:mol }\end{array}$} & \multirow{2}{*}{$\begin{array}{c}\text { Max } \\
\text { concentration } \\
\text { of aurumacryl } \\
\text { solution based } \\
\text { on total solids } \\
\text { concentration, } \\
\mathrm{mg} / \mathrm{ml}\end{array}$} & \multirow{2}{*}{$\begin{array}{c}\mathrm{A}_{226.5} \text { of the } \\
\text { concentrated } \\
\text { aurumacryl } \\
\text { solution, } \\
\mathrm{U} / \mathrm{ml}\end{array}$} & \multirow{2}{*}{$\begin{array}{l}\text { Concentration } \\
\text { of Au ions, } \\
\mathrm{mmol} / \mathrm{mg} \text { of } \\
\text { solids }\end{array}$} & \multicolumn{2}{|c|}{$\begin{array}{l}\text { Proportion of surviving } \\
\text { MCF-7 cells at aurumacryl } \\
\text { concentration } \mathrm{A}_{226,5} \\
\text { expressed as ml (MTT assay) }\end{array}$} \\
\hline & & & & & & & & $9.1 \mathrm{mU}$ & $91.0 \mathrm{mU}$ \\
\hline 1 & 5.7 & $100-300$ & $\mathrm{H}$ & $1: 32$ & 2.7 & 0.91 & 12.5 & 5 & 49 \\
\hline 2 & 3.0 & 1.6 & $\mathrm{H}$ & $1: 10$ & 29.4 & 2.40 & 32.8 & 5 & 51 \\
\hline 3 & 3.0 & 1.6 & $\mathrm{H}$ & $1: 10$ & 28.3 & 3.00 & 41.0 & 5 & 47 \\
\hline 4 & 3.0 & 11.5 & $\mathrm{H}$ & $1: 10$ & 29.4 & 1.00 & 15.5 & 5 & 21 \\
\hline 5 & 3.0 & 100 & $\mathrm{H}$ & $1: 10$ & 29.4 & 1.53 & 21.0 & 4 & 45 \\
\hline 6 & 3.0 & 100 & $\mathrm{H}$ & $1: 10$ & 33.3 & 3.00 & 41.0 & 5 & 46 \\
\hline 7 & 3.0 & 140 & $\mathrm{H}$ & $1: 5$ & 29.4 & 4.80 & 65.5 & 5 & 42 \\
\hline 8 & 3.0 & 140 & $\mathrm{H}$ & $1: 10$ & 29.4 & 2.00 & 23.6 & 4 & 51 \\
\hline 9 & 3.0 & 140 & $\mathrm{H}$ & $1: 10$ & 47.0 & 4.30 & 58.7 & 5 & 44 \\
\hline 10 & 3.0 & 250 & $\mathrm{H}$ & $1: 10$ & 29.4 & 2.00 & 24.2 & 4 & 60 \\
\hline 11 & 3.0 & 250 & $\mathrm{H}$ & $1: 10$ & 16.7 & 0.96 & 13.2 & 5 & 54 \\
\hline 12 & 0.1 & 250 & $\mathrm{H}$ & $1: 10$ & 4.2 & 0.77 & 10.5 & 6 & 43 \\
\hline 13 & 3.0 & 1000 & $\mathrm{H}$ & $1: 10$ & 29.4 & 0.56 & 7.7 & 5 & 44 \\
\hline 14 & 0.1 & 1000 & $\mathrm{H}$ & $1: 10$ & 5.0 & 0.69 & 9.4 & 6 & 49 \\
\hline 15 & 3.0 & 1.6 & $\mathrm{Na}$ & $1: 10$ & 29.4 & 1.27 & 17.4 & 5 & 45 \\
\hline 16 & 0.1 & 1.6 & $\mathrm{Na}$ & $1: 10$ & 27.3 & 0.39 & 5.4 & 6 & 41 \\
\hline 17 & 3.0 & 5.75 & $\mathrm{Na}$ & $1: 10$ & 29.4 & 1.00 & 14.8 & 6 & 39 \\
\hline 18 & 3.0 & 100 & $\mathrm{Na}$ & $1: 10$ & 29.4 & 1.00 & 18.4 & 4 & 39 \\
\hline 19 & 0.1 & 100 & $\mathrm{Na}$ & $1: 5$ & 12.6 & 2.58 & 35.3 & 6 & 46 \\
\hline 20 & 3.0 & 140 & $\mathrm{Na}$ & $1: 10$ & 29.4 & 1.33 & 18.2 & 11 & 42 \\
\hline 21 & 3.0 & 250 & $\mathrm{Na}$ & $1: 10$ & 29.4 & 1.30 & 17.8 & 6 & 44 \\
\hline 22 & 0.1 & 250 & $\mathrm{Na}$ & $1: 10$ & 13.3 & 0.37 & 5.2 & 7 & 41 \\
\hline 23 & 3.0 & 1000 & $\mathrm{Na}$ & $1: 10$ & 29.4 & 0.37 & 5.2 & 11 & 49 \\
\hline 24 & 0.1 & 1000 & $\mathrm{Na}$ & $1: 10$ & 10.0 & 0.54 & 7.5 & 9 & 38 \\
\hline
\end{tabular}

Note: Freeze-dried samples dissolved in water are shown in grey; other samples were not lyophilized but stored as solutions instead.

Table 2. Distribution of gold nanoparticle sizes in aurumacryl samples synthesized from PAA and PANa

\begin{tabular}{|c|c|c|c|c|c|c|c|}
\hline \multirow{2}{*}{$\begin{array}{l}M_{r} \text { of the polymer, } \\
\text { kDA }\end{array}$} & \multirow{2}{*}{ Counterion } & \multirow{2}{*}{$\begin{array}{l}\text { Molar ratio of } \mathrm{Au}(\mathrm{III}) \text { ions to PAA or PANa in } \\
\text { the reaction mixture, mol:mol }\end{array}$} & \multicolumn{5}{|c|}{ Proportion of nanoparticles of a given diameter, $\%$} \\
\hline & & & $1-10 \mathrm{~nm}$ & $11-20 \mathrm{~nm}$ & $20-50 \mathrm{~nm}$ & $50-100 \mathrm{~nm}$ & $>100 \mathrm{~nm}$ \\
\hline 1.6 & $\mathrm{H}$ & $1: 5$ & 76.0 & 14.0 & 10.0 & 0.0 & 0.0 \\
\hline 1.6 & $\mathrm{H}$ & $1: 10$ & 57.5 & 25.0 & 15.0 & 2.5 & 0.0 \\
\hline 11.5 & $\mathrm{H}$ & $1: 10$ & 84.0 & 12.0 & 4.0 & 0.0 & 0.0 \\
\hline 250 & $\mathrm{H}$ & $1: 10$ & 42.9 & 48.6 & 8.6 & 2.9 & 0.0 \\
\hline 1000 & $\mathrm{H}$ & $1: 10$ & 36.0 & 50.0 & 2.0 & 0.0 & 12.0 \\
\hline 11.5 & $\mathrm{Na}$ & $1: 5$ & 82.0 & 8.0 & 6.0 & 4.0 & 0.0 \\
\hline 140 & $\mathrm{Na}$ & $1: 5$ & 78.0 & 16.0 & 6.0 & 0.0 & 0.0 \\
\hline 140 & $\mathrm{Na}$ & $1: 10$ & 0.0 & 2.5 & 0.0 & 22.5 & 75.0 \\
\hline $100-300$ & $\mathrm{H}$ & $1: 0.0018$ & 46.7 & 23.3 & 30.0 & 0.0 & 0.0 \\
\hline
\end{tabular}




\section{DISCUSSION}

The tumoricidal effect of aurumacryl was investigated both in vivo and in vitro in the study [3]. The authors report that a single intraperitoneal injection of aurumacryl at a dose of $20 \mathrm{mg}$ per $1 \mathrm{~kg}$ mouse weight causes $80-90 \%$ growth inhibition of solid tumors in mice, including Lewis lung carcinoma, large intestine adenocarcinoma ACATOL and Ca-755 adenocarcinoma, in comparison with the controls. In the experiments in vitro the aurumacryl concentration of $1 \mathrm{mg} / \mathrm{ml}$ kills $\sim 70 \%$ of the MCF-7 cells (human breast carcinoma) by triggering both necrosis and apoptosis [3]. The mechanism of the selective tumoricidal effect of aurumacryl in vivo is yet to be elucidated; it is known, though, that gold ions do not selectively accumulate in the tumor following the intraperitoneal injection of aurumacryl but are evenly distributed in the body of the mouse and eliminated through excretion [3].

Over the past 3 years there have been reports that acrylic acid polymers can effectively deliver different cytotoxic and antiproliferative agents to cancer cells in vitro and in vivo (see below), meaning that polyacrylic particles of different molecular weight can selectively transport such agents to cancer cells and enhance their activity inside the cancer cell. Importantly, polyacrylates can selectively accumulate in dendritic cells and macrophages. This can improve the presentation of antigens carried by a polyacrylate agent to lymphoid cells as shown in the successful test of a polyacrylate conjugated to the peptide antigen mimetic of the HPV-16 oncoprotein 7 [4]. Polyacrylate particles immobilized inside the virus-like particles composed of the hepatitis B HBs-antigen enhanced the cytotoxic effect of doxorubicin [5]. There is evidence that peroxovanadate delivered to A495 lung carcinoma cells can effectively inhibit their growth [6]. Another study demonstrates a possibility of using theranostic polyacrylate-calcium phosphate complexes as carriers of gold nanoclusters in the therapy and diagnostic imaging of solid tumors [7].

Polyacrylic clusters can be used to deliver titanium oxide nanoparticles, ferromagnetic contrast agents, and salts and oxides of other metals to the tumor to increase its sensitivity to radiotherapy, achieve a cytotoxic effect or facilitate bioimaging based on the principles of fluorescence or magnetic resonance
[8-11]. Polyacrylate can be employed to deliver methylene blue used as a photosensitizer for contrast-enhanced radiotherapy to human breast carcinoma cells (MCF-7) [12]. All data mentioned here indirectly suggest that polyacrylates are capable of selectively targeting cancer cells in vivo. The underlying mechanism is unclear but the existing evidence leads us to hypothesize that PAA itself cannot exhibit cytotoxic activity against cancer cells. It is probably Au ions (III) carried by PAA that make the complex toxic for cancer cells.

This supposition can be confirmed by the findings of the study [13] of Au (III) compounds dichloro(ethylenediamine) aurum and dichloro(S-methyl-L-cysteine)aurum that exhibit pronounced cytotoxicity against human lymphoid leukemia cells. The authors of the study prove that just like cisplatin Au (III) ions can form DNA adducts in living cells causing their death.

The insufficient solubility of aurumacryl synthesized as described in [1] complicates the testing of its safety and therapeutic activity against cancer cells in biological models, as well as its use in clinical practice. The effective aurumacryl dose in the mouse model is $20 \mathrm{mg}$ per $1 \mathrm{~kg}$ body weight. The required concentration of aurumacryl in the solution would be $1 \mathrm{mg} / \mathrm{ml}$ [3]. Given that a mouse weighs about $20 \mathrm{~g}$, the volume of the injected solution would be $200 \mu \mathrm{L}$ per mouse, approaching the acceptable threshold: further increase in the injection volume would threaten the survival of mice regardless of the composition of the injected drug. Besides, dry samples stored at $+4{ }^{\circ} \mathrm{C}$ for 6 months show a sharp decline in their solubility.

By varying the parameters of the initial polymer and the molar ratio of PAA or PANa to chloroauric acid, we were able to study the impact of these factors on the reaction yield. We revealed that PAA concentrations in the produced aurumacryl and its molecular weight had almost no effect on the biological properties of the obtained substance. In contrast, the concentration of $\mathrm{Au}$ (III) ions measured from the absorbance of aurumacryl solutions $(\lambda=226.5 \mathrm{~nm})$ turned to be an accurate predictor of their in vitro cytotoxic activity in the cell culture.

However, the molar ratio of the polymer to $\mathrm{AuCl}_{4}^{-}$anions, the molecular weight of the polymer and the absolute concentration of the polymer solution have a profound impact on the gold ion concentration in the synthesized sample and

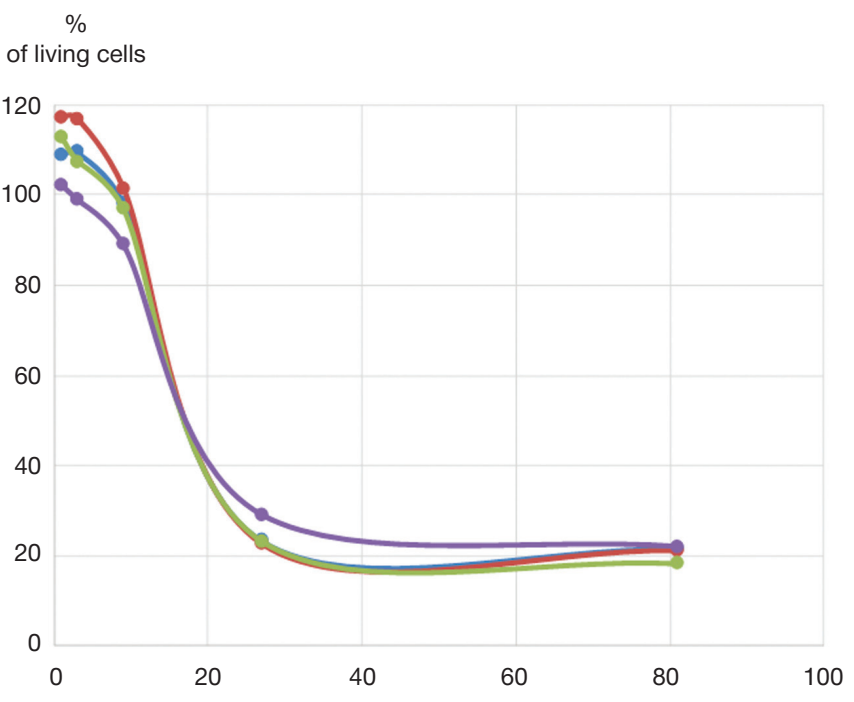

$\longrightarrow$ Favorsky Irkutsk Institute of Chemistry, Siberian branch of RAS $\multimap 3 \longrightarrow 10 \multimap 17$

Fig. 1. The graph shows a correlation between the Au (III) concentration in the tested aurumacryl samples and their cytotoxicity against human breast carcinoma cells (MCF-7). Concentrations at $A_{{ }_{2}}$ expressed as $\mathrm{mU}$ are plotted on the $\mathrm{X}$ axis. The proportion of the surviving cells measured by the $\mathrm{MTT}$ assay is plotted on the $\mathrm{Y}$ axis. The curves were constructed for samples 3, 10 and 17 synthesized in the course of this work and for the control sample synthesized at Irkutsk Institute of Chemistry (see Table 1). 
the solubility of the latter. In our experiment, the solubility of the sample was the highest when aurumacryl was synthesized from the polymers with polymerization degrees of 1,389 and 1,944 . The use of the polymers with higher molecular weight resulted in a slightly worse solubility of the aurumacryl sample if the initial polymer had the polymerization degree of 3,472 , and caused a dramatic drop in the solubility of the sample if the degree of polymerization was 13,889 . The use of the low molecular weight polymers with polymerization degrees of 23,80 and 160 enhanced the solubility of the synthesized substance in some cases, but because the produced substance tended to increasingly form nanoparticles, the reproducibility of the synthesis technique remained poor. The polymer with a polymerization degree of 1,389 was slightly less beneficial for the solubility of the sample than the polymer with a polymerization degree of 1,944.

The $1: 5$ molar ratio of chloroauric acid to the polymer with an average molecular weight of $140 \mathrm{kDa}$ ensured a slightly better reaction yield than the $1: 10$ ratio. The concentrated solution of the polyacrylate polymer (3\%) significantly increased the gold ion conversion in comparison with the diluted solution $(0.1 \%)$. The presence of $\mathrm{Na}^{+}$as a counterion for the carboxyl group of the polyacrylate polymer reduced the gold ion conversion by $10 \%$. Besides, the presence of $\mathrm{Na}^{+}$in the sample negatively affected the chemical stability of the samples during storage. The samples synthesized from PANa showed the signs of steady spontaneous reduction of $\mathrm{Au}$ (III) ions to metal nanoparticles regardless of the PANa molecular weight when stored at $+4{ }^{\circ} \mathrm{C}$ for $5-30$ days. Thus, pre-deionization of the polymer aimed at eliminating the cations of alkali metals is required to ensure the suitability of the polyacrylate polymer for aurumacryl synthesis.

Importantly, we revealed that the interaction between $\mathrm{AuCl}^{-}$ anions and the polyacrylate polymer can cause reduction of gold atoms to elemental gold aggregating into nanoparticles. This reaction results in the low gold conversion. We were able to come to this conclusion using transmission electron spectroscopy, which facilitates observation of electron-opaque particles securely attached to the polymer. The presence of gold nanoparticles of 1-100 nm in diameter in aurumacryl samples does not affect the cytotoxic activity of aurumacryl against MCF-7 cells at the studied range of concentrations: it only indirectly suggests that the proportion of bioactive gold ions decreases in such samples.

Based on the correlation between the concentration of gold ions measured from the absorbance at $226.5 \mathrm{~nm}$ and the cytotoxic activity of the obtained aurumacryl samples, we developed a method for assessing the quality of the synthesized aurumacryl. We applied this method to demonstrate that regardless of the synthesis technique and the molar ratio of $\mathrm{Au}$ ions to the polyacrylate polymer, the cytotoxicity of aurumacryl against the MCF-7cell line was proportional to its $A_{226.5}$. It means that aurumacryl quality assessment should include measurements of the absorbance of the saturated solution in the UV spectra at $\lambda=226.5 \mathrm{~nm}$. To avoid the impact of hydrolysis on the measurements, the analysis should be performed in the acidic media (such as $100 \mathrm{mM}$ of $\mathrm{HCl}$ ). Using this principle, we were able to assess the reaction yield and optimize the conditions of the reaction.
The fact that the concentration of gold ions in the sample is a predictor of aurumacryl toxicity against MCF-7 cells regardless of the concentration of the polyacrylate polymer in it, leads us to conclude that the polyacrylate polymer does not have a critical role in transporting gold ions into cancer cells or at least does not limit the efficacy of gold permeating the cell membranes in vitro. Still, it is possible that in in vivo experiments the role of the polyacrylate polymer in delivering the gold particles to the tumor is quite important. In order to investigate the properties of polyacrylate polymer carriers in biological systems, aurumacryl cytotoxicity needs to be studied first against other cell lines and primary cell cultures in vitro. Their nonspecific toxicity and tumoricidal effects should also be compared in vivo.

Unlike our colleagues who resorted to air-drying and used a vacuum exicator, we freeze-dried the obtained aurumacryl samples immediately after synthesis. This type of drying significantly improves the solubility of aurumacryl under physiological conditions up to $30 \mathrm{mg} / \mathrm{ml}$ of solids and ensures chemical stability necessary for long-term storage.

By optimizing the synthesis technique, we were able to obtain an aurumacryl solution with $A_{226.5}=4.8$ (equivalent to the optical path length of $1 \mathrm{~cm}$ ), which is 5.3 times higher than the best result demonstrated by the aurumacryl samples synthesized according to the original technique $\left(A_{226.5}=0.9\right)$. The cytotoxicity of our samples increases proportional to $A_{226.5}$. The use of concentrated solutions will facilitate the testing of aurumacryl biological activity in vivo and in vitro and promote the application of the compound as an tumoricidal agent in the future.

We believe that aurumacryl applications in medicine should not be limited to adjuvant chemotherapy of carcinomas. TEM findings suggest that aurumacryl is capable of forming gold nanoparticles when interacting with reductants. Considering the big atomic radius of gold, such particles can serve as radiosensitizers to enhance the effect of ionizing radiation on tumor cells [14]. This approach is underpinned by the affinity of aurumacryl to cancer cells discovered in this work and in [3], leading us to expect that gold nanoparticles will tend to selectively accumulate in malignant cells instead of healthy tissue.

\section{CONCLUSIONS}

By comparing the cytotoxicity of aurumacryl samples with significantly different molar ratio of gold ions to the polyacrylate polymers, we established that the proportion of the polymer and its molecular weight in the sample do not affect the biological properties of the synthesized substance. On the contrary, the concentration of $\mathrm{Au}$ (III) ions measured from the absorbance of aurumacryl solutions at $\lambda=226.5 \mathrm{~nm}$ is an accurate predictor of aurumacryl cytotoxicity against the MCF-7 cells in vitro. To synthesize the sample with the highest $\mathrm{Au}$ (III) conversion and the best solubility in water, free PAA should be thoroughly deionized prior to the synthesis. The recommended molecular weight of PAA is $140 \mathrm{kDa}$; its recommended concentration is $3 \%$. The molar ratio of chloroauric acid to PAA should be $1: 5$. It is important to freeze-dry the solution immediately after synthesis.

We hope that our findings will be useful for planning a preclinical trial of aurumacryl. 
1. Abzaeva KA, Belozerskaya GG, Malykhina LS, Zhilitskaya LV, Fedorin AYu, Bychichko DYu, et al. Incomplete golden salt of polyacrylic acid, method of its manufacturing and a medicine derived thereof exhibiting a hemostatic action up on external application. Patent RU \# 2607 519. Priority since Nov. 25. 2015. Published: Jan. 10. 2017, Bull. \# 1.

2. Makotchenko EV, Malkova VI, Belevantsev VI. Electronic absorption spectra of the gold (III) halide complexes in aqueous solutions. Rus J Coord Chem. 1999; 25 (4): 282-289.

3. Ostrovskaja LA, Korman DB, Grehova AK, Bljuhterova NV, Fomina MM, Rykova VA i dr. Jeksperimental'noe izuchenie protivoopuholevoj aktivnosti poliakrilata zolota. Rossijskij bioterapevticheskij zhurnal. 2018; 17 (5): 54-5.

4. Liu TY, Hussein WM, Giddam AK, et al. Polyacrilic-based delivery system for self-adjuvanting anticancer peptide vaccine. J Med Chem. 2015; (58): 886-96.

5. Biabanikhankahdani $\mathrm{R}$, Alitheen NB, Ho KL, Tan WS. pHresponsive Virus-like Nanoparticles with Enhanced Tumourtargeting Ligands for Cancer Drug Delivery. Sci Rep. 2016; 24 (6): 37891.

6. Chatterjll N, Anwar T, Islam NS, et al. Growth arrests of lung carcinoma cells (A549) by polyacryl-anchored peroxovanadat by activating Rac1-NADPH oxidase signaling axis. Mol Cell Biochem. 2016; (420): 9-20.

7. Li H, Hu J, Wu S, et al. Auranofin-mediated inhibition of PI3K/AKT/ mTOR axis and anticancer activity in non-small cell lung cancer cells. Oncotarget. 2016; (7): 3548-58.

\section{Литература}

1. Абзаева К. А., Белозерская Г. Г., Малыхина Л. С., Жилицкая Л. В., Федорин А. Ю., Бычичко Д. Ю. и др. Неполная золотая соль полиакриловой кислоты, способ ее получения и средство на ее основе, обладающее гемостатическим действием при наружном применении. Патент РФ № 2607 519. Приоритет 25.11.2015. Опубликовано: 10.01.2017, Бюл. № 1.

2. Макотченко Е. В., Малкова В. И., Белеванцев В. И. Электронные спектры поглощения галогенидных комплексов золота (III) в водных растворах. Координационная химия. 1999; 25 (4): 302-9.

3. Островская Л. А., Корман Д. Б., Грехова А. К., Блюхтерова Н. В., Фомина М. М., Рыкова В. А., и др. Экспериментальное изучение противоопухолевой активности полиакрилата золота. Российский биотерапевтический журнал. 2018; 17 (5): 54-5.

4. Liu TY, Hussein WM, Giddam AK, et al. Polyacrilic-based delivery system for self-adjuvanting anticancer peptide vaccine. J Med Chem. 2015; (58): 886-96.

5. Biabanikhankahdani R, Alitheen NB, Ho KL, Tan WS. pH responsive Virus-like Nanoparticles with Enhanced Tumourtargeting Ligands for Cancer Drug Delivery. Sci Rep. 2016; 24 (6): 37891.

6. Chatterill N, Anwar T, Islam NS, et al. Growth arrests of lung carcinoma cells (A549) by polyacryl-anchored peroxovanadat by activating Rac1-NADPH oxidase signaling axis. Mol Cell Biochem. 2016; (420): 9-20.

7. Li H, Hu J, Wu S, et al. Auranofin-mediated inhibition of PI3K/AKT/ mTOR axis and anticancer activity in non-small cell lung cancer cells. Oncotarget. 2016; (7): 3548-58.
8. Morita J, Kano K, Kato K, Takita H, Sakagami H, Yamamoto Y, et al. Structure and biological function of ENPP6, a choline-specific glycerophosphodiester-phosphodiesterase. Sci Rep. 2016; (6): 20995.

9. Nakayama M, Sasaki R, Ogino C, Tanaka T, Morita K, Umetsu M, et al. Titanium peroxide nanoparticles enhanced cytotoxic effects of X-ray irradiation against pancreatic cancer model through reactive oxygen species generation in vitro and in vivo. Radiat Oncol. 2016; 11 (1): 91

10. Lungu II, Rădulescu M, Mogoșanu GD, Grumezescu AM. pH sensitive core-shell magnetic nanoparticles for targeted drug delivery in cancer therapy. Rom J Morphol Embryol. 2016; 57 (1): 23-32.

11. $\mathrm{Xu} Y$, Sherwood JA, Lackey KH, Qin Y, Bao Y. The responses of immune cells to iron oxide nanoparticles. J Appl Toxicol. 2016; 36 (4): 543-53.

12. Khanal A, Bui MP, Seo SS. Microgel-encapsulated methylene blue for the treatment of breast cancer cells by photodynamic therapy. J Breast Cancer. 2014; 17 (1): 18-24.

13. Milovanović M, Djeković A, Volarević V, Petrović B, Arsenijević N, Bugarcić ZD. Ligand substitution reactions and cytotoxic properties of $[\mathrm{Au}(\mathrm{L}) \mathrm{Cl} 2]+$ and [AuCl2(DMSO)2]+ complexes (L-ethylenediamine and S-methyl-I-cysteine). J Inorg Biochem. 2010; 104 (9): 944-9.

14. Peukert D, Kempson I, Douglass M, Bezak E. Metallic nanoparticle radiosensitisation of ion radiotherapy: A review. Phys Med. 2018; (47): 121-8.

8. Morita J, Kano K, Kato K, Takita H, Sakagami H, Yamamoto Y, et al. Structure and biological function of ENPP6, a choline-specific glycerophosphodiester-phosphodiesterase. Sci Rep. 2016; (6): 20995.

9. Nakayama M, Sasaki R, Ogino C, Tanaka T, Morita K, Umetsu M, et al. Titanium peroxide nanoparticles enhanced cytotoxic effects of X-ray irradiation against pancreatic cancer model through reactive oxygen species generation in vitro and in vivo. Radiat Oncol. 2016; 11 (1): 91.

10. Lungu II, Rădulescu M, Mogoșanu GD, Grumezescu AM. pH sensitive core-shell magnetic nanoparticles for targeted drug delivery in cancer therapy. Rom J Morphol Embryol. 2016; 57 (1): 23-32.

11. $X u$ Y, Sherwood JA, Lackey KH, Qin Y, Bao Y. The responses of immune cells to iron oxide nanoparticles. J Appl Toxicol. 2016; 36 (4): 543-53.

12. Khanal A, Bui MP, Seo SS. Microgel-encapsulated methylene blue for the treatment of breast cancer cells by photodynamic therapy. J Breast Cancer. 2014; 17 (1): 18-24.

13. Milovanović M, Djeković A, Volarević $V$, Petrović B, Arsenijević N, Bugarcić ZD. Ligand substitution reactions and cytotoxic properties of $[\mathrm{Au}(\mathrm{L}) \mathrm{Cl} 2]+$ and [AuCl2(DMSO)2]+ complexes (L-ethylenediamine and S-methyl-I-cysteine). J Inorg Biochem. 2010; 104 (9): 944-9.

14. Peukert D, Kempson I, Douglass M, Bezak E. Metallic nanoparticle radiosensitisation of ion radiotherapy: A review. Phys Med. 2018; (47): 121-8. 